\title{
Dynamic Matrix for an Adaptive Environment Management in Mining: A Feed-engineering Alternative?
}

\author{
S. B. Mondoukpè Lagnika \\ École de technologie supérieure, Canada
}

\begin{abstract}
Robert Hausler
Department of construction engineering, École de technologie supérieure, Canada
\end{abstract}

\section{Mathias Glaus}

Department of construction engineering, École de technologie supérieure, Canada

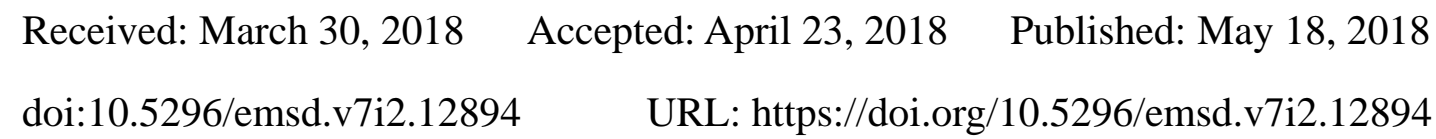

\begin{abstract}
Environment impacts are usually determined by quantification or an evaluation system derived from several methodologies including environmental assessment, matrices, and data cross-referencing. This study uses a dataset obtained from validated mining Environmental Impact Assessments (EIAs), some monitoring reports and scientific insights on open-pit mines (OPM). The purpose here is to build a dynamic matrix system over time to facilitate a systemic evaluation of environmental impacts and to find in-depth preventive measures in any OPM. The four dynamic matrices are built with qualitative and numerical values in both magnitude and significance terms. As one of the issues is to minimize negative risks in OPMs, one outcome points out the environmental factors of mining operations sensitive to the variations over time and the variability of the parameters themselves. The results show secondly that the data (qualitative and quantitative) vary from EIA stage to a post EIA status like activities or environmental factors numbers. Thirdly, the impact of activities on each part of environment components and the incidence of all activities during the mines' life cycle is easier to identify whatever the data density. In the fourth line, this paper indicates that the dynamic matrix in an optimal alternative in the process of determining preventive measures to mitigate the risks and the need for an interactive environmental follow-up program in
\end{abstract}


mining or similar industry. This approach reduces the following-up monitoring weaknesses and allows managers, as a multi-criterion decision-making approach, to take enlightened actions.

Keywords: Environmental monitoring, EIA, Matrix, Assessment, Over time, Risks, Open-pit, Follow-up program

\section{Introduction and Scope of Study}

Environmental assessment is an innovative tool that has revolutionized anthropogenic impacts on the environment and has improved since the Rio conference (Lagnika, 2009). Born in the 1970s, environmental assessment was established first to satisfy growing public concerns on our ecosystem but also to pursue and better develop industrial activities (Bouvier, 2006; Gorova, Pavlychenko, Borysovs'ka, \& Krups'ka, 2013). In order to reduce, regulate, control or adjust environmental risks arising from human activities, environmental impact assessment (EIA) is the best known tool to date before implementing any industrial projects (Evangelinos, Allan, Jones, \& Nikolaou, 2014). EIA, for its part, is a crucial internal step in any project involving negative impacts on the ecosystem where it must be implemented. In turn, EIA consists of two phases that best ensure the identification of risks: (1) corresponding mitigation measures and (2) monitoring of activities from construction to the end of industrial activities. Among all the industries, mining is the one who afflicts the whole environmental factors (geomorphic, soil, atmospheric, water, acoustical, social, vegetal, wildlife, financial and so on) (Chinbat, 2011; Pokhrel \& Dubey, 2013). Lagnika, Hausler, and Glaus (2017) and many other authors highlighted numerous risks associated with operation mining on the surrounding environment where the industry is based. In Canada and in Quebec, there are different impact assessment procedures by region, but in most of the cases, a mine exceeding 7000 Tons of minerals is subject not only to the EIA but also to a public hearing. These procedures are supposed to help managers to develop and operate their mining project in an environmentally responsible and safe manner at all levels for the benefit of communities and stakeholders. However, the observed data of EIA procedures under environment Act of Gouvernement du Canada (2017), environment quality Act of Gouvernement du Québec (2017a) and sustainable development Act Gouvernement du Québec (2017b) regulation respecting the review shown in figure 1 , form a sufficient composition which can enable a good management. 


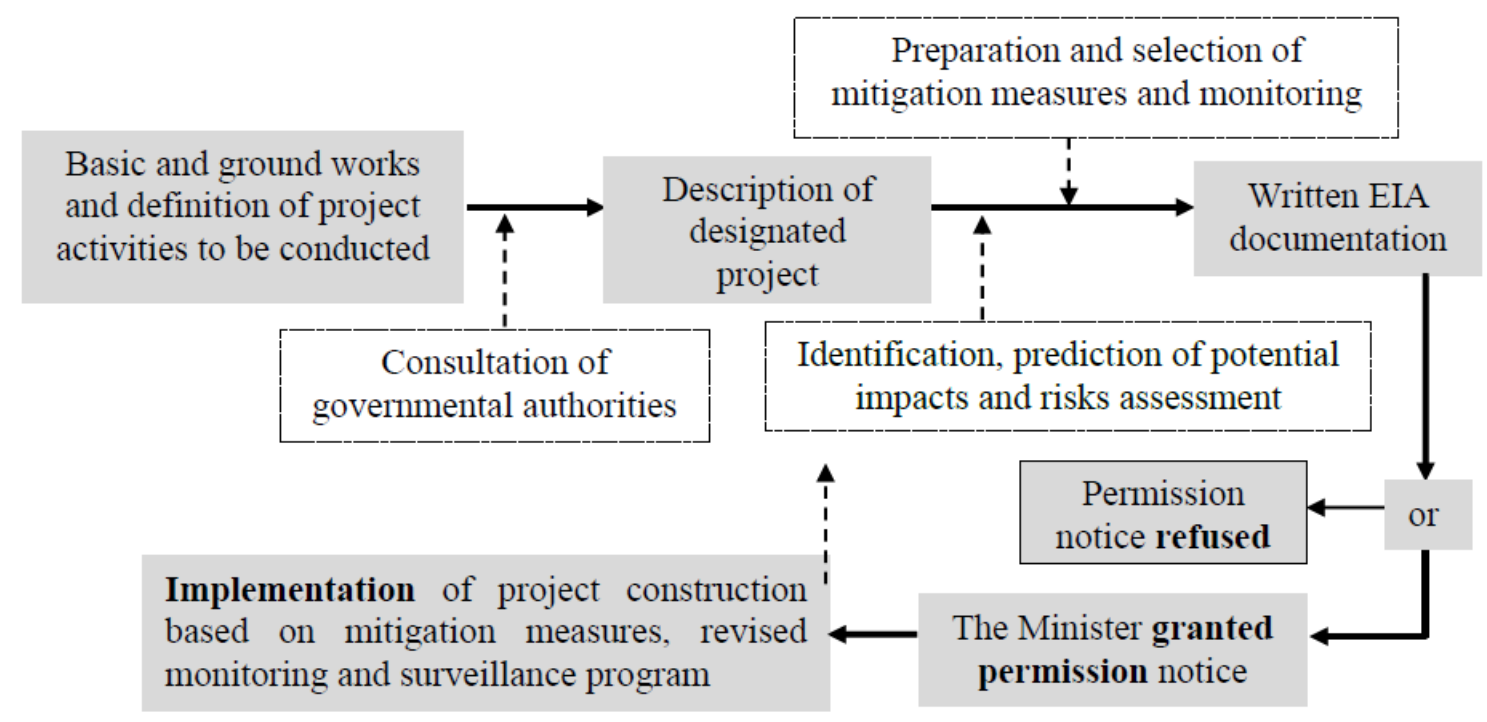

Figure 1. EIA regulation respecting Canada and Quebec laws. An adaptation of Canter

The procedure takes into account: the purpose of the project, the environmental effects of the mine preparation, their scope, the significance of the effects mentioned, public comments (public hearing), mitigation measures including feasible alternatives, the follow-up program, and monitoring. But, despite the effectiveness of EIA, there are still problems that disrupt the ecosystems once mines are put into operation. Some collapses or failures of dams occurred over the world are registered: a coal mine at Saunders (USA, 1972), in Stava (Italy, 1985), in Spain (1998), in Sweden (2000) and in an aluminium mine at Kolontar (Hungary, 2010). Also, authors notice significant pollution and environmental degradation around extraction operations and production processes (Kříbeka, De Vivob, \& Davies, 2014; Singh, Ihlenfeld, Oates, Plant, \& Voulvoulis, 2011). Others do not hesitate to expose the impacts of unbalancing incidences on basic human need as loss of soil fertility, air contamination by dust, health and safety issues, acidification of wastewater, destabilization of: groundwater, wildlife, geomorphology, etc. (Agbo \& Honkpehedji, 2009; Lagnika et al., 2017).

These are the reason why authors like Bouvier (2006) still consider that the potential of impact assessment is not exploited. Indeed, earlier Duinker (1989) argues that the basic goal of reducing risks in predictions is to generate a temporal time series of surveillance data and verify them. Actually, the EIA procedure requires environmental monitoring at the project construction but, the realization of a follow-up program at the end of the activities does not allow enough time to observe the evolution of the risks between the two big phases (project phase and operation phase). Bibliographic research carried out during this work through six scientific databases (Emerald Insight, Wiley \& son online, Engineering village, Google scholar, Taylor \& Francis and IEEE Xplore) revealed very few articles on Leopold's matrix, multi-criterion assessment studies and the weighting of impacts on many activities like irrigated dam but none in mining. Few investigations carried out on this topic between 1982, 1989 and 2017 highlight the weaknesses of environmental follow-up, which is the centerpiece of the EIA. These precedents show the lack of studies or investigations made by 
practitioners or scientists to improve more the tool which is useful for human activities and ecology control. In view of this inevitable livelihood of uncertainties in our dynamic ecosystems, MacKinnon (2017), insists recently for an ongoing adaptive approach to following-up environmental impacts. To do so, temporal data have to be set before the project construction and while the mine is put into operation. Then, depending on the severity of each risk and the mitigating or aggravating factors, the measures have to be chosen appropriately in order to know precisely and remedies widely the actions responsible for the negative impacts. Later, the action plan should be determined or adapted under the incurred circumstances.

\section{Research Methodology}

The aim of this paper is to carry out a dynamic matrix system to facilitate a systemic evaluation of environmental impacts and to observe the variability into the risk parameters in any OPM. An analytical framework of the obtained data as shown in figure 2 describes it. The methodology process is an evolving cycle that can be distilled down to six stages. First, the problematic is identified. Secondly, the grid holds the information and criteria around specific inclusion and exclusion factors.

The inclusion factors are: "to be a mining organization that operates as an open-pit and to obtain the permission notice from the government's. The exclusion factors are to be: "an underground mine or an open-pit mines (OPM) organization that has not yet obtained the permission notice/ an OPM that cannot produce more than 7,000 tons because this is not subject to EIA/ a proposed expansion and development of OPM or not/ an OPM with an incomplete EIA". Representative OPM data from the literature review and EIA that have been approved by the government, will serve as a basis for these numerical and qualitative analyses.

So, following the step of the selection of these factors, a technical review of the assessments, 11 EIA reports with public hearing reports shown in the Table 1, several scientific articles, technical reports, federal and provincial legislation were studied in depth. From those results, the environmental factors, the significance of the impacts according to the value of the environmental component (VEC) as well as the intensity with the extent, were determined and harmonized throughout this work. Then, the matrices were developed and later, a sensitivity analysis was done to compare the results from EIA step to the post-EIA step. 


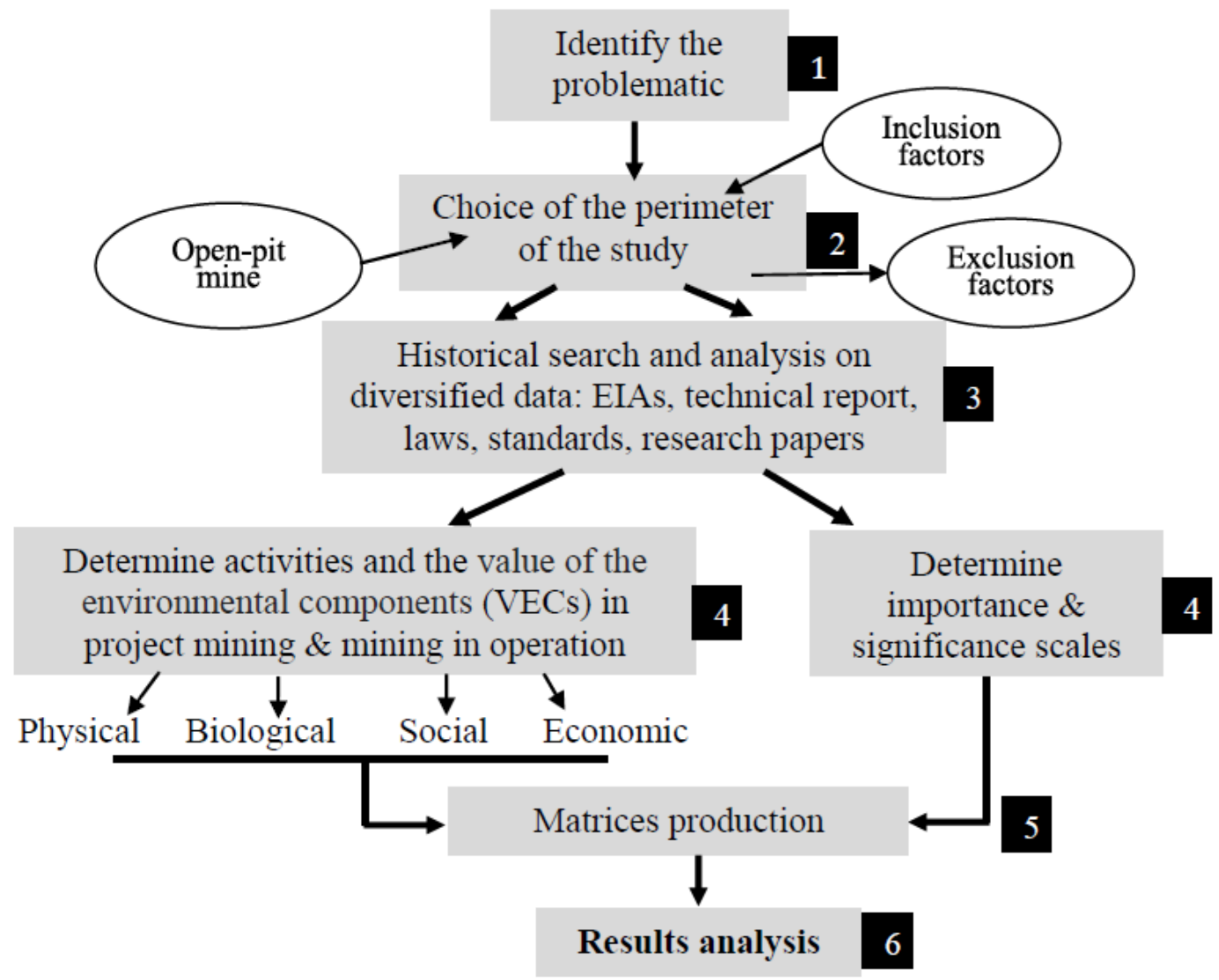

Figure 2. Description of the work methodology

Table 1. Summary of the EIA or public hearing reports studied

\begin{tabular}{|l|l|l|}
\hline & EIA or Public hearing reports & References \\
\hline 1 & Sisson mine project & New Brunswick (2015) \\
\hline 2 & Apatite mine & BAPE (2013) \\
\hline 3 & Coal mine & Alberta government (2012) \\
\hline 4 & Kitsault Mine & $\begin{array}{l}\text { Agence canadienne d'évaluation environnementale (2013); } \\
\text { Amec Foster Wheeler (2012) }\end{array}$ \\
\hline 5 & Akasaba west project mine & WSP Global (2015) \\
\hline 6 & Whabouchi mine & $\begin{array}{l}\text { Nemaska lithium and Agence canadienne d'évaluation } \\
\text { environnementale (2013) }\end{array}$ \\
\hline 7 & Beaver dam mine & $\begin{array}{l}\text { Agence canadienne d'évaluation environnementale } \\
\text { and Atlantique Gold Corporation (2017) }\end{array}$ \\
\hline 8 & Niocan project mine & Roche ltée (2000) \\
\hline 9 & Arnaud inc. project mine & Roche ltée (2012) \\
\hline 10 & Apatite project mine in Paul lake & Genivar (2013) \\
\hline 11 & Bloom Lake Iron Mine & Genivar (2006) \\
\hline
\end{tabular}

\subsection{Study of Area}

This work considered the review of 11 open pit mines across Canadian provinces summarized 
in the previous Table 1. It also took account of the inclusion and exclusion factors (previous section 2), with their approved public hearing reports and environmental compliance certificates.

\subsection{EIA and Ni 43-101: What is the Difference?}

The Canadian government designates a mine as any set of surface or underground infrastructure intended for the extraction of minerals (Gouvernement du Québec, 2011; Ministère du Développement durable de l'Environnement et des Parcs, 2012; Québec, 2017). This activity is subject to several laws, regulations, standards and requires any manager not only to submit an EIA but also a technical document that serves as a national instrument called Ni 43-101 (Autorité des marchés financiers, 2016). Ni 43-101 is a technical report that includes an all-round form, all material scientific, mineral-physical aspects and technical data concerning the mining project. It is about to provide specific details concerning mineral exploration, development, and production activities in a mining area by a qualified person. This technical report, which is intended for the investing public and its advisors, may contain information similar to what is used in an EIA, but it remains simplified on environmental issues of this activity. The reader should note that the $\mathrm{Ni} 43-101$ reports have only been considered partially.

As the decisions or predictions must be made, it would, therefore, be wise to make an up-to-date assessment of the potential impacts on OPM and its operating parameters before continuing this study. Holling (1978), Rist, Felton, Samuelsson, Sandström, and Rosvall (2013) identified all the interactions of any ecosystem, the components and the uncertainties as obstacles to any adaptive management. Such a broad spectrum of impacts and risky situations because of problematics due to their complexity which are not always well or sufficiently understood in the available data.

\subsection{Activities and the Value of the Environmental Component'S (Vecs) in Project Mining and} Mining in Operation

The variables retained were: the mining activities from the project to the termination and the environmental factors considered in the literature consulted on OPMs. Table 1 and 2 provide a detailed list of environmental factors and mining operations at mining project status and once the mine is operational. These two categories of detailed lists confirm the dynamic temporal notion designated for the purpose of this research. But preliminary studies for the realization of matrices go beyond EIAs studied to get this detailed list. Indeed, the categorization performed required a historical search data on the environmental impacts of mining operations as well as the monitoring of the historical evolution of the EA in the industry. Then, this has resulted in a thorough consultation of the existing legislation and standards related to the activity. Also, the historical data from government bodies and BAPE registers help to shape, invalidate or confirm the existence of risk situations, impacts as well as the relevance of dynamic parameters to be considered and the extent of environmental damage caused. The environmental factors and sub-factors were collected from gray literature, scientific databases, available EIAs, few $\mathrm{Ni}$ 43-101, scientific articles, organizational or government documents, and other reports or briefs. The cause-and-effect 
relationships between actions and VECs have been studied through EIAs reports and in-depth reports to attain and recapitulate the impacts close to the ground situation.

Table 2. Summary of environmental factors or valued components of the environment (VEC)

\begin{tabular}{|c|c|c|c|}
\hline \multirow{2}{*}{\multicolumn{2}{|c|}{ VECs }} & \multicolumn{2}{|c|}{ STATUS } \\
\hline & & \multirow{2}{*}{$\begin{array}{r}\text { PROJECT } \\
\text { Morphology }\end{array}$} & \multirow{2}{*}{$\begin{array}{l}\text { REALIZED } \\
\text { Morphology }\end{array}$} \\
\hline Geomornhology & Landscape & & \\
\hline Geomorphology & Topography & Geography & Geography \\
\hline \multirow{7}{*}{ Pedology } & \multirow{2}{*}{ Ground } & Quality of the soil resources & Quality of the soil resources \\
\hline & & Surface deposit & Surface deposit \\
\hline & \multirow{5}{*}{ Subsoil } & Geology & Geology \\
\hline & & Geotechnical conditions & Geotechnical conditions \\
\hline & & Sediments & Sediments \\
\hline & & Erosion & Erosion \\
\hline & & Sterile and residues & Sterile and residues \\
\hline \multirow{5}{*}{ Atmostpheric } & \multirow{3}{*}{ Air } & Quality & Quality \\
\hline & & Pollution & Pollution \\
\hline & & $\begin{array}{l}\text { Emission and deposition of } \\
\text { dust }\end{array}$ & Emission and deposition of dust \\
\hline & \multirow{2}{*}{ Climate } & Microclimate & Microclimate at workstations \\
\hline & & Suspended particles & Microclimate \\
\hline \multirow{3}{*}{ Acoustic } & Noise & Level & Suspended particles \\
\hline & & Noise pollution & Level \\
\hline & Vibration & $\begin{array}{l}\text { Vibration level or air } \\
\text { overpressures }\end{array}$ & Noise pollution \\
\hline \multirow{4}{*}{ Vegetal } & \multirow{4}{*}{ Flora } & Species at risk & Vibration level or air overpressures \\
\hline & & Density and diversity & Species at risk \\
\hline & & Aquatic plants & Density and diversity \\
\hline & & Wet areas & Aquatic plants \\
\hline \multirow{8}{*}{ Wildlife } & \multirow{2}{*}{ Animals } & Habitats & Wet areas \\
\hline & & Density and diversity & Habitats \\
\hline & \multirow{2}{*}{ Aquatic species } & Species at risk & Density and diversity \\
\hline & & Invasive species & Species at risk \\
\hline & \multirow{2}{*}{ Mammals } & Species at risk & Species at risk \\
\hline & & Most abundant species & Most abundant or common species \\
\hline & \multirow{2}{*}{ Birdlife } & Species at risk & Species at risk \\
\hline & & Most abundant species & Most abundant species \\
\hline \multirow{5}{*}{ Water } & \multirow{5}{*}{ Surface water } & Morphology of waters & Invasive species \\
\hline & & Flow / Debit & Morphology of waters \\
\hline & & Level & Flow / Debit \\
\hline & & Sedimentary regime & Level \\
\hline & & Groundwater & Sedimentary regime \\
\hline
\end{tabular}




\begin{tabular}{|c|c|c|c|}
\hline & \multirow{4}{*}{$\begin{array}{l}\text { Groundwater / } \\
\text { Aquifers }\end{array}$} & Debit & Groundwater \\
\hline & & Quality & Debit \\
\hline & & Level & Quality \\
\hline & & Hydrogeological conditions & Level and infiltration \\
\hline & \multirow{5}{*}{ Runoff waters } & Erosion & Flood \\
\hline & & Effluent quality & Hydrogeological conditions \\
\hline & & Flow / Flow & Erosion \\
\hline & & Water level & Effluent quality \\
\hline & & Retention basins & Flow / Debit \\
\hline Economic & Finances & $\begin{array}{l}\text { Stimulation of the local } \\
\text { economy }\end{array}$ & Water level \\
\hline \multirow{21}{*}{ Social } & \multirow{5}{*}{ Sociocultural } & Value and land use & Retention basins \\
\hline & & Famous heritages & Stimulation of the local economy \\
\hline & & Religious monuments & Value and land use \\
\hline & & Middle traditions & Famous or known heritages \\
\hline & & Tourism and Leisure & Religious monuments \\
\hline & \multirow{2}{*}{ Health } & Health infrastructures & Middle traditions \\
\hline & & Diseases & Tourism and Leisure \\
\hline & Security & Security level & Health infrastructures \\
\hline & \multirow{5}{*}{ Human capital } & Population and characteristics & Epidemics \\
\hline & & Employability level & Diseases \\
\hline & & $\begin{array}{l}\text { Sectors of activity known to the } \\
\text { project community }\end{array}$ & Accidents \\
\hline & & Housing & Occupational injuries \\
\hline & & Immigration & Security level \\
\hline & \multirow{8}{*}{ Governance } & \multirow{8}{*}{ Social responsibility } & Population and characteristics \\
\hline & & & Employability level \\
\hline & & & $\begin{array}{l}\text { Sectors of activity known to } \\
\text { the project community }\end{array}$ \\
\hline & & & Housing \\
\hline & & & Immigration \\
\hline & & & Social responsibility \\
\hline & & & Conflicts of interest and management \\
\hline & & & Ethics and corruption \\
\hline
\end{tabular}




\section{Macrothink}

Environmental Management and Sustainable Development

ISSN 2164-7682

2018, Vol. 7, No. 2

Table 3. Summary of activities or mining operations in an OPM

\begin{tabular}{|c|c|c|}
\hline Site preparation \& Construction & Operation \& Maintenance & $\begin{array}{c}\text { Closure \& rehabilitation of } \\
\text { the operated site }\end{array}$ \\
\hline Observation and mapping of the terrain & Drilling and blasting rock & Demolition of infrastructure \\
\hline $\begin{array}{l}\text { Exploration, sampling and sampling of } \\
\text { geological and geotechnical data }\end{array}$ & Storing blasting products & $\begin{array}{l}\text { Integrity of works (supervision } \\
\text { and maintenance work) }\end{array}$ \\
\hline $\begin{array}{l}\text { Assessment of the potential for structural } \\
\text { instability }\end{array}$ & Crushing and grinding & Environmental monitoring \\
\hline Mineral resource estimate & Washing & Rehabilitation of the land \\
\hline $\begin{array}{l}\text { Completion of other related studies such } \\
\text { as EIA with assessment of the cost of } \\
\text { restoration }\end{array}$ & $\begin{array}{l}\text { Sieve and particle size } \\
\text { distribution if applicable }\end{array}$ & $\begin{array}{l}\text { Monitoring the quality of the } \\
\text { effluent }\end{array}$ \\
\hline Clearing, stripping, weeding, cleaning & Collection & $\begin{array}{l}\text { Monitoring the quality of } \\
\text { groundwater }\end{array}$ \\
\hline Drying and leveling & Transport of chemicals & $\begin{array}{l}\text { General management of } \\
\text { residues }\end{array}$ \\
\hline Trench opening at the deposit & $\begin{array}{l}\text { Concentration and processing } \\
\text { of ore }\end{array}$ & Agronomic monitoring \\
\hline $\begin{array}{l}\text { Management of topsoil, till and waste } \\
\text { rock }\end{array}$ & $\begin{array}{l}\text { Evacuation of water and } \\
\text { effluents from the open pit }\end{array}$ & \\
\hline Drilling and blasting / felling of rock & Ore transport & \\
\hline $\begin{array}{l}\text { Disposal of water from the settling pond } \\
\text { (if it existed) }\end{array}$ & $\begin{array}{l}\text { Management and handling of } \\
\text { ore in terminal phase }\end{array}$ & \\
\hline $\begin{array}{l}\text { Changes to watercourses and wetlands (if } \\
\text { applicable) }\end{array}$ & $\begin{array}{l}\text { Management of waste rock and } \\
\text { tailings }\end{array}$ & \\
\hline $\begin{array}{l}\text { Construction of site roads and installation } \\
\text { of surface lighting, including lighting }\end{array}$ & Surface water management & \\
\hline Slope construction & $\begin{array}{l}\text { Management of petroleum } \\
\text { products }\end{array}$ & \\
\hline $\begin{array}{l}\text { Installation and construction of } \\
\text { infrastructures }\end{array}$ & Fuel warehouse & \\
\hline $\begin{array}{l}\text { Pit design (geological, economic, financial } \\
\text { and operational considerations) }\end{array}$ & Fire and management & \\
\hline $\begin{array}{l}\text { Excavation of the catch basin and settling } \\
\text { basin }\end{array}$ & Slope failure & \\
\hline Installation of on-site lighting & Spills of fuel or other spills & \\
\hline $\begin{array}{l}\text { Warehouse for blasting / slaughtering } \\
\text { products }\end{array}$ & $\begin{array}{l}\text { Site maintenance, repairs and } \\
\text { installation of lighting }\end{array}$ & \\
\hline Lighting of transport routes & $\begin{array}{l}\text { Failure of the catch basin or } \\
\text { settling basin }\end{array}$ & \\
\hline $\begin{array}{l}\text { Operations involving the use of mobile } \\
\text { equipment }\end{array}$ & $\begin{array}{l}\text { Environmental monitoring at } \\
\text { predetermined intervals }\end{array}$ & \\
\hline
\end{tabular}




\section{Ml Macrothink}

These initial categorization phases made it possible to obtain a readily, expanded and available spectrum of knowledge of dynamics resources, mining operations and VECs that will be used to design and develop the matrices.

\subsection{Importance and Significance Calculation}

Several matrices have been developed for different specific applications and among them, Leopold's matrix is the most general with a wider application. In this term, Josimovic, Petric, and Milijic (2014) show how the matrix draws a clear line and safeguards of evaluation synthesis from value judgments or policy makers to present a detailed assessment results. Initially, Leopold matrix is a semi-qualitative environmental impact assessment method pioneered in the last century by Leopold, Clarke, Hanshaw, and Balsley (1971). So, by facilitating the interactive participation of varied, hierarchical and antagonistic experts with stakeholder knowledge or opinions as valid input to research in an inexact research area, this matrix is an adequate tool according to Hai, Gobin, and Hens (2014). But, its most distinctive feature is his allowance to meta-analysis of issues to be investigated. This matrix provides a multi-criteria assessment of the possible impacts of an organization's activities in the project stage. Also, matrix tool like Leopold's can take into account both quantitative and qualitative data that correspond to the values found and this is the exact context of environmental studies.

The matrix is built by a detailed list of mining operations in the vertical axis and a system of selected factors in the horizontal axis. It is presented as a cross-functional table with different box where significant interaction is marked symbolically or by calculated values.

Under the quotation system indicated below in table 4, the magnitude and significance of each impact are respectively calculated. Then, some statement of activities and environmental factors are retained. According to logic matrices development, the importance of impacts (see Appendix A) and the qualitative analysis, the weighting is substantially similar. The weighting here varies from 1 to 10 both for the magnitude and significance of the impacts. Some values can go beyond 10 but, when this maximum is reached, it's maintained at 10. It's important to note that another purpose of this paper is to generate a matrix of OPM in operation.

Table 4. Determination of the significance value of an environmental impact

\begin{tabular}{|c|c|c|c|c|c|c|c|}
\hline $\begin{array}{l}\text { Weight } \\
\text { (W) }\end{array}$ & $\begin{array}{c}\text { Magnitude (M) } \\
\text { ou severity }\end{array}$ & $\mathbf{W}$ & Time (T) & $\mathbf{W}$ & $\begin{array}{c}\text { Probability } \\
\text { (P) }\end{array}$ & Corresponding weight & Significance \\
\hline $1-3$ & Negligible & 1 & Punctual & 1 & Rare & \multirow{4}{*}{$\begin{array}{c}\mathbf{M}+\mathbf{T}+\mathbf{P}=\mathbf{I} \\
\mathbf{N B} \text { : if } \mathbf{I}>\mathbf{1 0} \text { then the } \\
\text { weighting of } \mathbf{I} \text { remains } \mathbf{1 0}\end{array}$} & Negligible \\
\hline $4-6$ & Low & 2 & Medium & 2 & Likely & & Low \\
\hline $7-8$ & Median & 3 & Long term & 3 & Effective & & Medium \\
\hline $9-10$ & $\begin{array}{l}\text { Strong or } \\
\text { irreversible }\end{array}$ & 4 & Irreversible & & & & Strong \\
\hline
\end{tabular}

\section{Analysis of Results}

The objective of this extensive work is to present an enhanced dynamic matrix system to 
facilitate a systemic evaluation of environmental impacts in any OPM. It also aims to observe the variability in the parameters related to the risks. These approaches reduce the following-up monitoring weaknesses and allow managers to assess the efficiency of mitigation measures. As this research aim is to minimize negative risks on OPMs sites, this research outcomes point out all the environmental factors sensitive to the variations over time of mining operations as well as the variability of the parameters themselves (from the project to the operating step).

\subsection{Recapitulation of Potential Environmental Risks and Activities in OPM}

The summary of mining activities or operations in OPM shows many fluctuations from one state to another. Table 3 lists the mining activities from the site preparation to the closure and rehabilitation of the mined ore site. But as it is shown in table 5, these activities vary once operations are executed. There are more than 4 activities in addition to those listed in an EIA. After preparation and construction, the operations, increase to thirteen activities once the mine is in operation. It should also be noted that the volume of an operation becomes larger after getting the permission notice. In the same way, there are fluctuations in environmental parameters from a mining project to a mine in operation. Table 2, shows some elements of the major groups of factors known as physical, biological and human, which can increase tenfold in several different sub-activities. Indeed, the predictions of risks may require reviews, additions, derivatives or duplications to follow closely.

Table 5. Fluctuations in the activities listed at the EIA elaboration and after the mine in operation

\begin{tabular}{|c|c|}
\hline EIA matrix & Matrix post EIA \\
\hline Slope construction & \multirow{8}{*}{ No activities to mention } \\
\hline Installation and construction of infrastructure & \\
\hline $\begin{array}{l}\text { Pit design (geological, economic, financial } \\
\text { and operational considerations) }\end{array}$ & \\
\hline Excavation of the catch basin and settling basin & \\
\hline Installation of on-site lighting & \\
\hline Warehouse for blasting / slaughtering products & \\
\hline Lighting of transport routes & \\
\hline Operations involving the use of mobile equipment & \\
\hline Drilling and blasting rock & Drilling and blasting rock \\
\hline Storing blasting products & Storing blasting products \\
\hline Crushing and grinding & Loading, crushing and grinding \\
\hline Washing & Excavation of fragmented blocks \\
\hline Sieve and particle size distribution if applicable & $\begin{array}{l}\text { Collection and loading of ore blocks } \\
\text { in trucks by skips or shovels }\end{array}$ \\
\hline \multirow[t]{3}{*}{ Collection of ore } & Ore transport before primary treatment \\
\hline & $\begin{array}{l}\text { Temporary storage of ore, where appropriate, } \\
\text { according to form and areas }\end{array}$ \\
\hline & Wash if necessary \\
\hline
\end{tabular}




\begin{tabular}{|c|c|}
\hline & $\begin{array}{l}\text { Temporary storage } 2 \text { of the ore if necessary } \\
\text { according to the form and the area }\end{array}$ \\
\hline & Grinding if necessary \\
\hline & Sieve and particle size distribution if applicable \\
\hline & Sorted ore pickup if required \\
\hline Transport of chemicals & Chemical transport and unloading \\
\hline \multirow[t]{2}{*}{ Concentration and processing of ore } & Concentration and processing of ore \\
\hline & Storage of residues \\
\hline Evacuation of water and effluents from the open pit & Evacuation of water and effluents from the open pit \\
\hline Ore transport & Ore transport \\
\hline \multirow[t]{3}{*}{ Management and handling of ore in terminal phase } & Handling of terminal ore for shipping or sale purposes \\
\hline & Transport of domestic and mining waste \\
\hline & Waste rock management \\
\hline Management of waste rock and tailings & Management of tailings \\
\hline \multirow[t]{2}{*}{ Surface water management } & Surface water management \\
\hline & Maintenance of rolling stock \\
\hline Management of petroleum products & Reception of petroleum products \\
\hline Fuel warehouse & Fuel warehouse \\
\hline \multirow[t]{3}{*}{ Fire and management } & Fire: Crisis situation \\
\hline & Fire: Prevention and Emergency Plan \\
\hline & Management in case of fire \\
\hline Slope failure & Slope failure \\
\hline \multirow[t]{2}{*}{ Spills of fuel or other spills } & Spills of fuel or other spills \\
\hline & Temporary plant shutdowns for maintenance \\
\hline Site maintenance, repairs and installation of lighting & Site maintenance, repairs and installation of lighting \\
\hline Failure of the catch basin or settling basin & Failure of the catch basin or settling basin \\
\hline Environmental monitoring at predetermined intervals & Environmental monitoring at predetermined intervals \\
\hline Demolition of infrastructure & $\begin{array}{l}\text { Demolition of infrastructure according to the } \\
\text { restoration program selected }\end{array}$ \\
\hline $\begin{array}{l}\text { Integrity of works (supervision and maintenance } \\
\text { works) }\end{array}$ & $\begin{array}{l}\text { Integrity of works (supervision and maintenance } \\
\text { works) }\end{array}$ \\
\hline Environmental monitoring & Environmental monitoring \\
\hline Rehabilitation of the land & $\begin{array}{l}\text { Rehabilitation of the land according to the } \\
\text { restoration program selected }\end{array}$ \\
\hline Monitoring the quality of the effluent & Monitoring the quality of the effluent \\
\hline Monitoring the quality of groundwater & Monitoring the quality of groundwater \\
\hline General management of residues & $\begin{array}{l}\text { General management of residues } \\
\text { (domestic, mining, waste and other waste) }\end{array}$ \\
\hline Agronomic monitoring & Agronomic monitoring \\
\hline
\end{tabular}

\subsection{Qualitative and Quantitative Data from Matrix of Symbol Values or Numerical Matrix}

This section summarizes the project phase and operation phase impacts of the physical, 
biological, and social-economic-cultural components in OPM. A quick summary of the data output shows that the data vary from a matrix at EIA stage to a post-EIA status not only because of the activity or the affected environmental factors level but also fluctuate quantitatively (numerical) and qualitatively (symbolic). These analyses assume that activities or environmental components could change speedily, promptly or briefly over time and between processes. Two types of dense matrices were developed: symbolic and numeric (see Appendix B and C). The symbolic matrix cannot be considered as the numerical matrix. Its data remain qualitative and the conclusions are approximate since the majority is retained. For its own part, the numerical matrix provides with much greater detail on the: 1) need to make environmental monitoring more dynamic and therefore interactive; 2) ecological significance of such effects; and 3) emphasis on environmental factors and the mining system. Such details on the basis of regular updates that come with the evolution of the environmental risks during the lifetime of the mine.

\subsubsection{Qualitative Data Results from the Matrices with Symbol Values}

Table 6. Qualitative data results on an open-pit mine (OPM) project

\begin{tabular}{|l|l|l|l|l|l|l|l|l|}
\hline $\begin{array}{l}\text { Impact } \\
\text { typology }\end{array}$ & $\begin{array}{l}\text { Positive but } \\
\text { negligible }\end{array}$ & $\begin{array}{l}\text { Minor } \\
\text { positive }\end{array}$ & $\begin{array}{l}\text { Positive } \\
\text { average }\end{array}$ & $\begin{array}{l}\text { Major } \\
\text { positive }\end{array}$ & $\begin{array}{l}\text { Negative but } \\
\text { negligible }\end{array}$ & $\begin{array}{l}\text { Minor } \\
\text { negative }\end{array}$ & $\begin{array}{l}\text { Negative } \\
\text { average }\end{array}$ & $\begin{array}{l}\text { Major } \\
\text { negative }\end{array}$ \\
\hline Synthesis & 4 & 14 & 53 & 145 & 32 & 162 & 329 & 323 \\
\hline
\end{tabular}

Table 7. Qualitative data results on post EIA of OPM

\begin{tabular}{|l|l|l|l|l|l|l|l|}
\hline $\begin{array}{l}\text { Impact } \\
\text { typology }\end{array}$ & $\begin{array}{l}\text { Positive but } \\
\text { negligible }\end{array}$ & $\begin{array}{l}\text { Minor } \\
\text { positive }\end{array}$ & $\begin{array}{l}\text { Positive } \\
\text { average }\end{array}$ & $\begin{array}{l}\text { Major } \\
\text { positive }\end{array}$ & $\begin{array}{l}\text { Negative but } \\
\text { negligible }\end{array}$ & $\begin{array}{l}\text { Minor } \\
\text { negative }\end{array}$ & $\begin{array}{l}\text { Negative } \\
\text { average }\end{array}$ \\
\hline Synthesis & 0 & 28 & 37 & 75 & 101 & 123 & 533 \\
\hline
\end{tabular}

Table 6 and 7 present the synthesis values of the results from the numerical matrix, which clearly, demonstrates the negative environmental risk activity that mining represents even if there is a considerable rate of positive impacts.

In addition to this outcome from the qualitative data, it is interesting to point out, on the one hand, the impact of activities on each part of environment components and in the second hand, the incidence of all mining activities during the mines' life cycle.

\subsubsection{Quantitative Data Results from the Numerical Matrices}

In each impact cell of the numerical matrix, there are two numbers above and below the diagonal of each cell, respectively, indicating magnitude (from 1 to 10) and significance of the impact (from 1 to 10). Negative values do not always appear with the symbol (-) but the cell is always coloured whilst the positive cells are colourless. The calculation is simple and is limited to the sum of the values depending on the activities on the line of each factor of the affected environment.

Therefore, the magnitude weight of «construction of site roads and installation of surface lighting» impact on geomorphological resources equals: $(-) 7[7(+0)=(-) 7]$. The significance weight of «construction of site roads and installation of surface lighting» impact on 


\section{Macrothink}

Environmental Management and Sustainable Development

ISSN 2164-7682

2018, Vol. 7, No. 2

geomorphological resources equals: $(-) 10:[10+0=(-) 10]$. It is the same rule about positive impacts. But they always appear in unstained cells and since they are positive symbol in front of their numbers is always the $(+)$ even if the sign does not appear in front of the number.

\subsubsection{Summary of Matrices Analysis}

Here, the results report the general degree of impacts of the project phase on different parameters, which are already known in the scientific literature, but not in this kind of numerical and symbolic details, for a total of six assessment table matrices.

Table 8. Environmental mining assessment scores on the project phase and post EIA phase

\begin{tabular}{|l|c|c|c|c|c|c|c|c|c|}
\hline \multirow{2}{*}{ Project phase } & \multicolumn{4}{|c|}{ PHYSICAL } & \multicolumn{3}{c|}{ BIOLOGY } & \multicolumn{3}{c|}{ HUMAN } \\
\cline { 2 - 12 } & Geomorphological & Soil & Air & Acoustic & Vegetal & Wildlife & Water & Economic & Social \\
\hline Magnitude - & 85 & 229 & 354 & 248 & 235 & 639 & 592 & 107 & 414 \\
\hline Significance - & 131 & 345 & 551 & 384 & 355 & 721 & 949 & 149 & 554 \\
\hline Magnitude + & 10 & 30 & 9 & 7 & 39 & 88 & 58 & 130 & 872 \\
\hline Significance + & 12 & 44 & 17 & 13 & 44 & 101 & 91 & 181 & 1177 \\
\hline
\end{tabular}

\begin{tabular}{|l|c|c|c|c|c|c|c|c|c|}
\hline \multirow{2}{*}{ Post-EIA phase } & \multicolumn{4}{|c|}{ PHYSICAL } & \multicolumn{3}{c|}{ BIOLOGY } & \multicolumn{3}{c|}{ HUMAN } \\
\cline { 2 - 13 } & Geomorphological & Soil & Air & Acoustic & Vegetal & Wildlife & Water & Economic & Social \\
\hline Magnitude - & 99 & 499 & 980 & 472 & 137 & 478 & 898 & 99 & 1389 \\
\hline Significance - & 134 & 134 & 1267 & 623 & 179 & 663 & 1180 & 111 & 1728 \\
\hline Magnitude + & 15 & 28 & 18 & 2 & 32 & 109 & 94 & 110 & 1367 \\
\hline Significance + & 19 & 41 & 30 & 3 & 53 & 135 & 254 & 152 & 1452 \\
\hline
\end{tabular}

Legend: $\quad$ Negatives values;

Positives values

The table 8 lists two elements of the environmental factors negative scores for the project phase with the post-EIA phase in both magnitude and significance terms of general parameters.

\subsubsection{Scores and Sensitivity Analysis: Project and Post-EIA phases}

Figure 3 shows a picture of a table built in Microsoft excel to perform sensitivity analysis whose a clearer presentation is in Appendix D.

\begin{tabular}{|c|c|c|c|c|c|c|c|c|c|c|c|c|c|c|c|c|c|c|}
\hline \multirow{3}{*}{$\begin{array}{l}\text { Environmental } \\
\text { components }\end{array}$} & \multicolumn{8}{|c|}{ PHYSIQUE } & \multicolumn{6}{|c|}{ BOLOGIQUE } & \multicolumn{4}{|c|}{ HUMAN } \\
\hline & & thologital & & Soil & & Air & & ustic & & getal & & Idlife & & ater & & nomic & & iocial \\
\hline & $\begin{array}{l}\text { Project } \\
\text { phase }\end{array}$ & $\begin{array}{l}\text { Operation } \\
\text { phase }\end{array}$ & $\begin{array}{l}\text { Project } \\
\text { phase }\end{array}$ & $\begin{array}{l}\text { Operation } \\
\text { phase }\end{array}$ & $\begin{array}{l}\text { Projett } \\
\text { phase }\end{array}$ & $\begin{array}{l}\text { Operation } \\
\text { phase }\end{array}$ & $\begin{array}{l}\text { Projett } \\
\text { phase }\end{array}$ & $\begin{array}{l}\text { Operation } \\
\text { phase }\end{array}$ & $\begin{array}{l}\text { Project } \\
\text { phase }\end{array}$ & $\begin{array}{l}\text { Operation } \\
\text { phase }\end{array}$ & $\begin{array}{l}\text { Projett } \\
\text { phase }\end{array}$ & $\begin{array}{l}\text { Operation } \\
\text { phase }\end{array}$ & $\begin{array}{l}\text { Project } \\
\text { phase }\end{array}$ & $\begin{array}{l}\text { Operation } \\
\text { phase }\end{array}$ & $\begin{array}{l}\text { Project } \\
\text { phase }\end{array}$ & $\begin{array}{l}\text { Operation } \\
\text { phase }\end{array}$ & $\begin{array}{l}\text { Project } \\
\text { phase }\end{array}$ & $\begin{array}{l}\text { Operation } \\
\text { phase }\end{array}$ \\
\hline $\begin{array}{l}\text { Final negative } \\
\text { results }\end{array}$ & & & & & & & & & & & & & & & & & & \\
\hline
\end{tabular}

Figure 3. Overview of the environmental components family score 


\section{Macrothink}

Environmental Management and Sustainable Development

ISSN 2164-7682

2018, Vol. 7, No. 2

Table 9. Summary of magnitude and significance of negative risks

\begin{tabular}{|l|c|c|c|c|c|c|}
\hline \multirow{2}{*}{} & \multicolumn{2}{|c|}{ PHYSICAL } & \multicolumn{2}{c|}{ BIOLOGY } & \multicolumn{3}{c|}{ HUMAN } \\
\cline { 2 - 7 } & $\begin{array}{c}\text { Project } \\
\text { phase }\end{array}$ & $\begin{array}{c}\text { Operation } \\
\text { phase }\end{array}$ & $\begin{array}{c}\text { Project } \\
\text { phase }\end{array}$ & $\begin{array}{c}\text { Operation } \\
\text { phase }\end{array}$ & $\begin{array}{c}\text { Project } \\
\text { phase }\end{array}$ & $\begin{array}{c}\text { Operation } \\
\text { phase }\end{array}$ \\
\hline Magnitude of negatives impacts score & -1388 & -1578 & -1466 & -1513 & -521 & -1488 \\
\hline Significance of negatives impacts score & -1411 & -2158 & -2025 & -2022 & -703 & -1839 \\
\hline
\end{tabular}

The analysis of the numerical matrix at the post EIA stage highlights the high rate of negative risks on all physical, biological and human environmental factors. But, even in terms of physical and human factors, there is a growing difference between the magnitude and significance of risks, as from the project stage to the operational stage. However, the risks related to the biological factors from the beginning of the project to the operation phase maintain a regular, high rate but almost invariant as presented in the precedent table 9.

The figure 4 below describes how negative risks appear to be less important in EIA development but take on greater importance or are more affected once the mine is in operation. This vulnerable group of risky situations is a normal phenomenon that needs the attention of stakeholders, especially since this step is longer than the project phase.

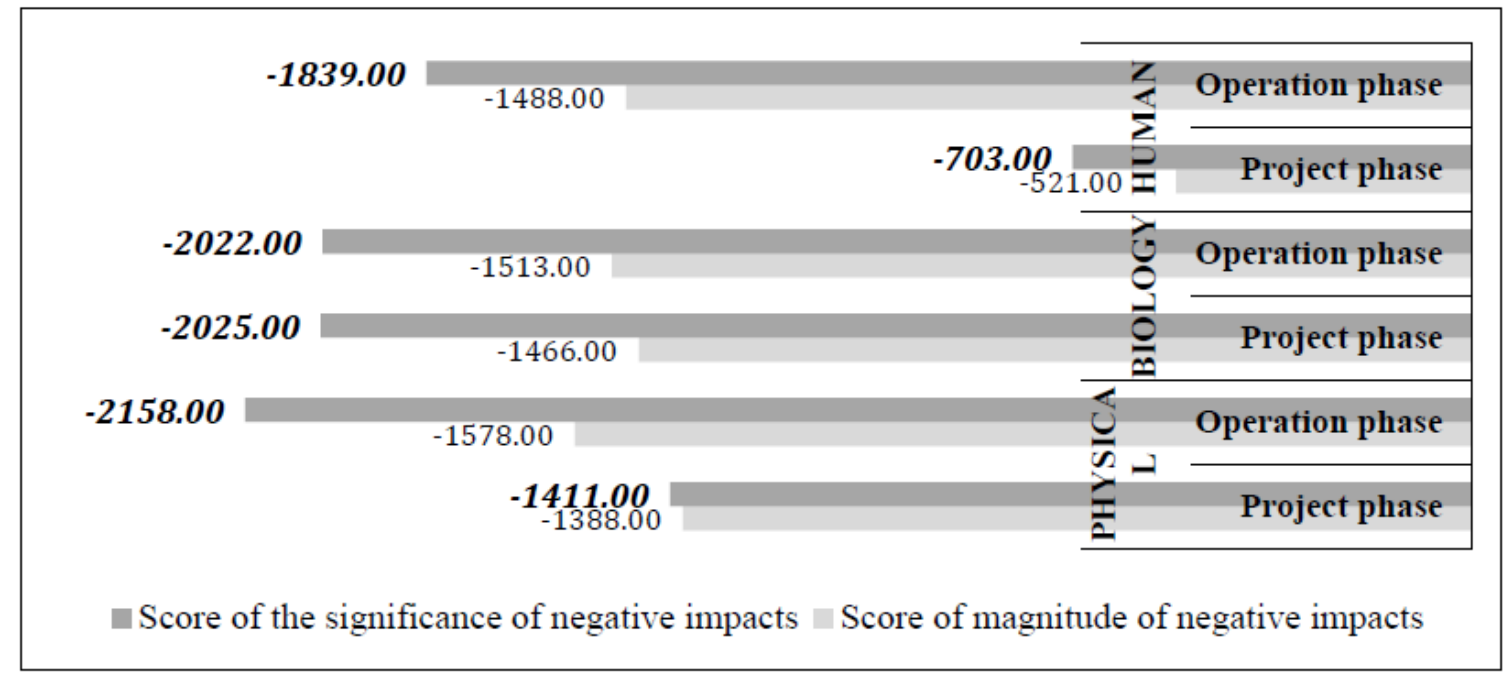

Figure 4. Plotted results of comparison importance level between negatives environmental risks

By observing the results, we notice that the negative risks, even if their weighting remains very high, the fact is that effect of the positive economic impacts is higher.

Table 10. Environmental factors parameters in order taken into account in the sensitivity analysis

\begin{tabular}{|c|c|c|c|c|c|c|c|c|}
\hline $\mathbf{1}$ & $\mathbf{2}$ & $\mathbf{3}$ & $\mathbf{4}$ & $\mathbf{5}$ & $\mathbf{6}$ & $\mathbf{7}$ & $\mathbf{8}$ & $\mathbf{9}$ \\
\hline \multicolumn{3}{|c|}{ PHYSICAL } & \multicolumn{3}{c|}{ BIOLOGY } & \multicolumn{3}{c|}{ HUMAN } \\
\hline Geomorphological & Soil & Air & Acoustic & Vegetal & Wildlife & Water & Economic & Social \\
\hline
\end{tabular}

Geomorphological, soil, air, acoustic, vegetal, wildlife, water, economic and social 


\section{Macrothink}

Environmental Management and Sustainable Development

ISSN 2164-7682

2018, Vol. 7, No. 2

parameters are considered in the sensitivity analyses in order to gain insight into the proposed hypothesis. In order to simplify the reading, these environmental factors are represented by numbers 1 through 9 in the order as shown in the table 10.
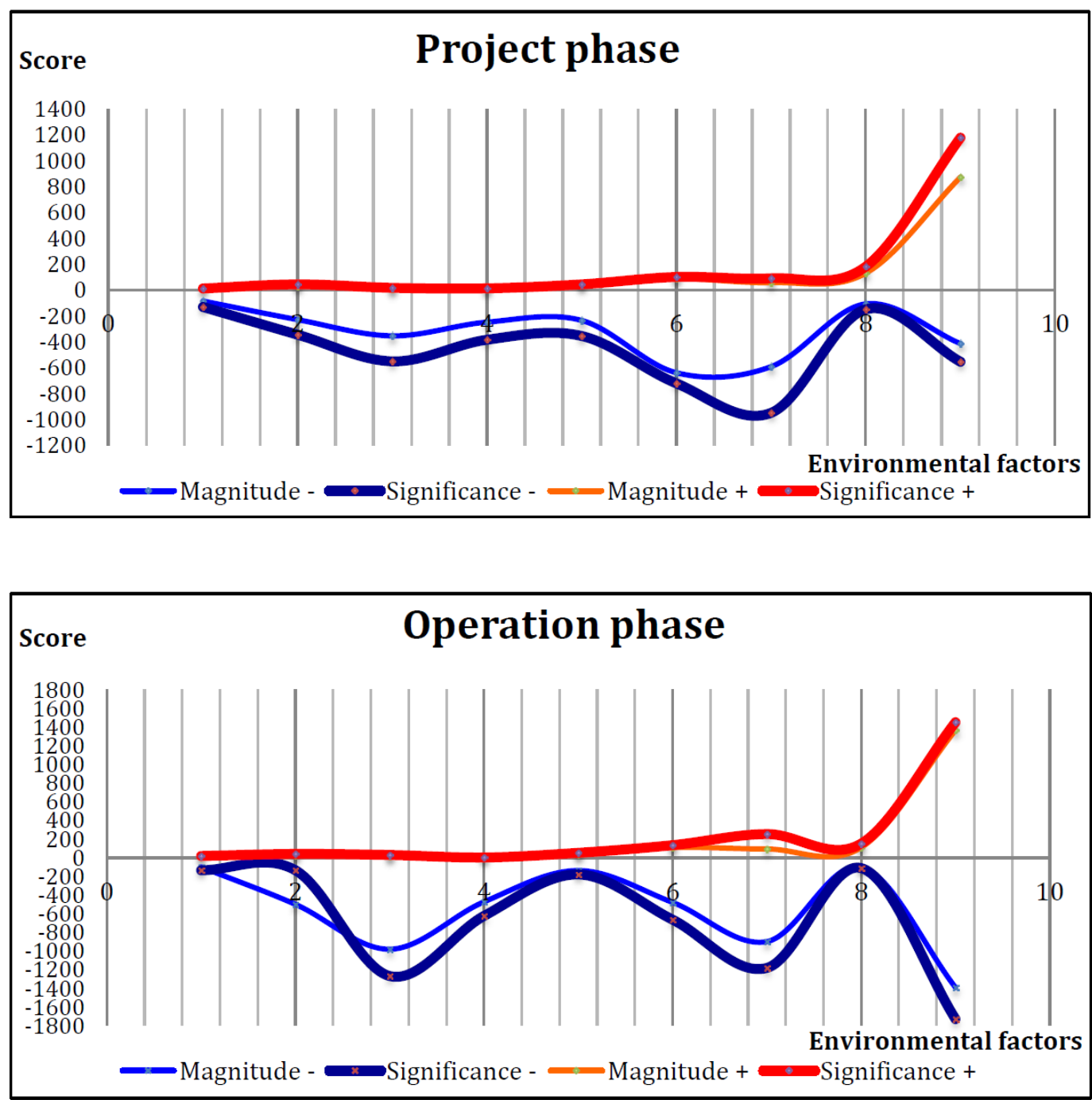

Figure 5. Sensitivity analysis: magnitude and significance risks evolution from project to operation phase depending on environmental factors

\subsection{Disparities between the Level of Magnitude and Importance of Risks Observed}

The results of these sensitivity analyses shown in figure 5 show a considerable disparity between the impacts weight on the VECs. These disparities between the level of magnitude and significance of environmental risks after summation of impact scores led to determine adverse or unavoidable impacts and the corresponding parameters to follow up. Indeed, by fluctuating over time, some variability parameters are highlighted and must be monitored. The figures also expose the magnitude and the significance of the negative risks especially, over time which joins the previous deductions. Soil, air, acoustic, wildlife, water and social are these factors subject to variations to follow closely. 
Positive impacts do not need to be mentioned because they are not sources of harm to the ecosystem. But it remains necessary to emphasize that there are positive values because this investigation from the beginning takes into account the principles of wastewater management. A principle that any mine manager or other industrial infrastructure must have. However, the apparent invariability of factors 1, 5 and 8 (geomorphology, flora and the human) mean something else. They demonstrate their dependence on the other environmental factors.

\section{Discussion}

This paper brings round a new execution methodology mode of the assessment process to take appropriate mitigation measures for responsible environmental management in mining. The work proposes a technical approach with a major review process (of risks, VECs) useful for a better decision-making process for both academicians and practitioners. A necessity, since the alert is put forward by some authors like MacKinnon, Duinker, and Walker (2018) on the need to reconcile environmental management to a more adapted scientific methodology. Furthermore, to better ensure the EIA procedure to dynamic simulation technique, the research gives three specific contributions: 1) evolution, extent, significance, and magnitude of incurred risks; 2) the mitigation measures strategies by reading data horizontally or vertically; and 3) environmental mining management and dynamic monitoring options.

\subsection{Evolution, Extent, Significance, and Magnitude Data}

After collecting OPMs that met the criteria defined (exclusion and inclusion) a synthesis of the environmental parameters in different scientific languages has been made. This harmonization led to the reduction of repetitions, to a systemic summary of the considered factors in the mining industry and an appropriate outreach to all stakeholders. At the end of this first exercise, 58 environmental factors have been listed as shown in table 2 against 65 factors to the phase of mining operations. Subsequently, a summary of activities or operations is conducted for these mining activities in the state of exploration, project, construction, operation, and closure of the mine. 42 different activities are retained in the matrices of the operation phase compared to 50 in the project phase because that includes the exploratory and construction steps (see table 5). And the probabilities of negative or positive impacts spread across 2900 cells at the project phase (50 activities x 58 factors) and 2730 at the operational phase (42 activities x 65 factors). Then, the obtained impacts are individually (according to each activity) or sequentially, numerically, qualitatively and therefore globally also (due to aggravating factors). But, even if the negative risks are greater than the positive impacts, the 2900 and 2730 probabilities respectively do not make all impacts as shown sensitivity analyse (figure 5). Finally, the matrices highlight: 1) the potential environmental risks (from negligible to major); 2) the development or evolution of risks over time between the phases; 3 ) the interaction of risks with the other components of the system; 4) and their amplitude followed by their significance on all affected environmental factors.

\subsection{Mitigation Measures Strategies: Horizontal and Vertical Data}

The results show that the incidences of mining activities during the lifetime of the mine are 
multiple and have complex causes due to interactions between operations and environmental factors. In order to remove or reduce negative environmental impacts, mitigation measures are identified right from the project conception. There are two known types: suppression and reduction measures at the source. In general, the suppression measures correspond to the alternative of eliminating impacts at the source (Baard, 2014; Gouvernement du Québec, 2018). They require a revision of the initial project by reconsidering aspects of development and exploitation. This in order to eliminate the negative impacts on the natural environment or the species exposed. While if a negative impact cannot be removed, the reduction measures serve to limit the influence of the anticipated negative impacts. The reduction measures may apply from time to time from the design of the project to the construction, operation and maintenance phases too. In this work, due to the observed changes and fluctuations in the weight of the impacts, an optimal application of mitigation measures is essential before the project construction and during the operations. However, such a measure will depend on the temporal behaviour of the risks and the concerned environmental factors. An approach facilitated here by computing horizontally and vertically the impacts scores.

When the obtained data are combined vertically, the scoring show how dangerous is each activity on each VECs and the stakeholders can choose another way to make this operation if it remains essential. When it is horizontally, the manager is able to better measure the sensitivity of environmental factors over the lifetime of the mine. By taking the example of a physical factor on noise pollution, major negative impacts remain throughout the life of the mine and will make the environment unbearable if no mitigation or suppression is taken. Moreover, as the mine gets older, a concentration of negative risks is more observed. These are the aspects that should challenge the parties involved in readjusting the environmental management of mining to increase the frequency of environmental monitoring so as to closely monitor sensitive factors and subject to strong and dangerous fluctuations.

\subsection{Environmental Mining Management and Dynamic Monitoring Options}

Indeed, the elaborated matrices ensure a temporal risk representation, from the mining project to, the mine in operation. The ability to provide values close to the realities of the environment over time is a particularly important aspect that directs the players in the environmental management of mining towards the integration of dynamics. This approach can serve as a bridge to dynamic management and the use of a dynamic simulation (DSi) in environmental procedures as analysed by Lagnika et al. (2017) by creating dynamic matrices for an adaptive management. The generated risk sheet can also serve as a basic reference for managers and users of EIA projects for mining projects from now on and within the framework of the environmental management.

The variations observed between the two phases confirm the importance of being careful about environmental factors changes or transformations or behaviour over time. Also, when an environmental component experiences a series of negative impacts as undergo the security, noise pollution, water, effluent quality, flora, etc. evidence of a regular environmental monitoring program with a rigorous application is a visible recommendation to adopt. 


\section{Conclusion}

Properly managing environmental risks is at the top priority of many actors in the mining sectors' agendas. However, the process of sorting measures to mitigate or prevent risks and the monitoring program are most of the time structured in theory but often unstructured during the production. This failure or irregularity was also reflected in this academic research literature performed in this study.

And, even if there are more than hundred or thousand EIA studies realized in the world in mining, there are also more than a hundred methodologies used for. Yet, the harmonization of proceedings seems to be a meaningful way to recommend. To improve the environmental performance of mines and the performance of operations, this work helps practitioners to invest themselves in an adaptive environmental assessment and management by creating models of monitoring matrices. The establishment of a matrix as a primary tool for access clearance the negative, positive or negligible environmental risks at the project (with EIA) and the operation (post-EIA) phases, required elements from several orders to reflect the reality of extractive industries. Therefore, by dynamic symbolic manipulations and numerical solving or inferences, this is a contribution to a useful production information system for OPMs in Canada like elsewhere in the world and allowed to make an in-depth prevention of impacts. These dynamic matrices should be required hereafter in the environmental monitoring program and integrated into the mining plan to improve mitigation measures over time. And, systemically by a reverse engineering, here is a way to obtain values reflecting approximately the reality of the: evolution, extent, significance, and magnitude incurred during the mining's lifecycle.

As MacKinnon (2017) maintain that the global environment assessment (EA) enterprise is to fulfil the purpose to contribute to a sustainable pattern of development by protecting VECs, the researchers and practitioners must adopt a more collaborative, participatory, and scientifically rigorous approach to conduct future EAs.

\section{Acknowledgment}

The Ecole de technologie supérieure (ETS) supported this work via the following programs: Experimental station of pilot processes in the environment (STEPPE-ÉTS) and research officers. We also thank all the reviewers for their constructive comments.

\section{References}

Agbo, S. J. A., \& Honkpehedji, R. N. (2009). Analyse des déterminants de la production des cultures vivrières au Bénin: cas du maïs et de l'igname (Mémoire de 2e cycle). Université Abomey-Calavi (UAC), Abomey-Calavi, Bénin.

Agence canadienne d'évaluation environnementale, \& Atlantique Gold Corporation. (2017). Étude d'impact environnemental du projet de la mine Beaver Dam. Marinette (Nouvelle-Écosse): Agence canadienne d'évaluation environnementale.

Agence canadienne d'évaluation environnementale. (2013). Projet minier Kitsault - Rapport d'étude approfondie. Ottawa, Ontario: Agence canadienne d'évaluation environnementale. 


\section{Macrothink}

Environmental Management and Sustainable Development

ISSN 2164-7682

2018, Vol. 7, No. 2

Alberta government. (2012). Vista Coal Mine Project - Environmental impact assessment. Yellowhead County, Alberta: Alberta government.

Amec Foster Wheeler. (2012). Projet minier Kitsault - Kitsault mine project environmental assessment. Prince Rupert, CB: A. F. Wheeler.

Autorité des marchés financiers. (2016). Règlement 43-101 sur l'information concernant les projets miniers - chapitre V-1.1, r. 15. (Ch V-1.1, r. 15). Québec, QC: Autorité des marchés financiers Retrieved from

https://lautorite.qc.ca/fileadmin/lautorite/reglementation/valeurs-mobilieres/43-101/2016-0509/2016mai09-43-101-vofficielle-fr.pdf.

Baard, P. (2014). Risk-reducing goals: ideals and abilities when managing complex environmental risks. Journal of Risk Research, 19(2), 164-180.

https://doi.org/10.1080/13669877.2014.961513

BAPE. (2013). Projet d'ouverture et d'exploitation d'une mine d'apatite à Sept-Îles. Québec, Québec: BAPE.

Bouvier, A. L. (2006). L'évolution de l'évaluation des impacts depuis le début des années 1970 : Le cas des grands barrages hydroélectriques au Québec. (Maîtrise). Université du Québec à Montréal, Montréal.

Canter, L. W. (1982). Environmental impact assessment. Impact Assessment, 1(2), 6-40. https://doi.org/10.1080/07349165.1982.9725447

Chinbat, U. (2011). Risk Analysis in the Mining Industry. In M. Savino (Ed.), Risk management in Environment, Production and Economy (pp. 103-122). Mongolie: InTech.

Duinker. (1989). Ecological effects monitoring in environmental impact assessment: What can it accomplish? Environmental Management, 13(6), 797-805. https://doi.org/10.1007/BF01868319

Evangelinos, K. I., Allan, S., Jones, K., \& Nikolaou, I. E. (2014). Environmental management practices and engineering science: A review and typology for future research. Integrated environmental assessment and management, 10(2), 153-162. https://doi.org/10.1002/ieam.1504

Genivar. (2006). Projet de mine de fer du lac Bloom, Consolidated Thompson Iron Mines Limited (CLM): étude d'impact - Rapport principal (Q104949). Sept-îles, Québec: Bureau d'Audiences Publiques sur l'Environnement.

Genivar. (2013). Projet de mine d'apatite du lac à Paul. Étude d'impact sur l'environnement. Rapport principal (N/Réf : 121-24005-00). Baie Comeau, QC: Bureau d'Audiences Publiques sur l'Environnement.

Gorova, A., Pavlychenko, A., Borysovs'ka, O., \& Krups'ka, L. (2013). The development of methodology for assessment of environmental risk degree in mining regions. Paper presented at the Annual Scientific-Technical Colletion - Mining of Mineral Deposits 2013, Balkema, 
Netherland. https://doi.org/10.1201/b16354-38

Gouvernement du Canada. (2017). Loi canadienne sur l'évaluation environnementale. (L.C. 2012, ch. 19, art.52). Ottawa, Ontario: Gouvernement du Canada, Retrieved from http://laws-lois.justice.gc.ca/PDF/C-15.21.pdf.

Gouvernement du Québec. (2011). Loi sur les mines. (M-13.1). Québec, Québec: Publications du Québec Retrieved from

http://www2.publicationsduquebec.gouv.qc.ca/dynamicSearch/telecharge.php?type=2\&file=/ M_13_1/M13_1.html.

Gouvernement du Québec. (2017a). Loi sur la qualité de l'environnement. (Chapitre Q-2). Québec, Québec: Publications du Québec, Retrieved from http://legisquebec.gouv.qc.ca/fr/pdf/cs/Q-2.pdf.

Gouvernement du Québec. (2017b). Règlement sur l'évaluation et l'examen des impacts sur l'environnement - Loi sur la qualité de l'environnement (chapitre Q-2, a. 31, 31.1, 31.3, 31.9 et 124.1). (Chapitre Q-2, r. 23). Québec, QC: Publications du Québec, Retrieved from http://legisquebec.gouv.qc.ca/fr/ShowDoc/cr/Q-2, r. 23.

Gouvernement du Québec. (2018). Loi sur la santé et de la sécurité du travail. Québec, Canada: Yvon Blais.

http://www2.publicationsduquebec.gouv.qc.ca/dynamicSearch/telecharge.php?type=2\&file=/ S_2_1/S2_1.html

Hai, L. T., Gobin, A., \& Hens, L. (2014). Uncovering causes and effects of desertification using a Leopold matrix in Binh Thuan Province, Vietnam. Chinese journal of population resources and environment, 12(1), 57-67. https://doi.org/10.1080/10042857.2014.883052

Holling, C. S. (1978). Adaptive environmental assessment and management (Vol. 3). Chinchester, USA: International institute for Applied Systems Analysis.

Josimovic, B., Petric, J., \& Milijic, S. (2014). The use of the leopold matrix in carrying out the eia for wind farms in serbia. Energy and Environment Research, 4(1), 43-54.

https://doi.org/10.5539/eer.v4n1p43

Kř́beka, B., De Vivob, B., \& Davies, T. (2014). Special Issue: Impacts of mining and mineral processing on the environment and human health in Africa. Journal of Geochemical Exploration, 144(Part C), 387-390. https://doi.org/10.1016/j.gexplo.2014.07.018

Lagnika, M. S. (2009). La gestion des risques environnementaux au sein des entreprises immobilières. (Maîtrise). Université du Québec à Montréal, Montréal, Canada.

Lagnika, M. S., Hausler, R., \& Glaus, M. (2017). Modeling or dynamic simulation: a tool for environmental management in mining? Journal of Integrative Environmental Sciences, 14(1), 19-37. https://doi.org/10.1080/1943815X.2017.1294607

Leopold, L. B., Clarke, F., Hanshaw, B., \& Balsley, J. (1971). A procedure for evaluating environmental impact. Geological Survey Circular, No. 645(1), 1-13. 
MacKinnon, A. J. (2017). Implementing science in environmental assessment - A review of theory. (Partial fulfilment report for the degree of Master of environmental studies). Dalhousie University, Halifax, Nova Scotia.

MacKinnon, A. J., Duinker, P. N., \& Walker, T. R. (2018). The Application of science in environmental impact assessment (Vol. 1). London, UK: Routledge.

Ministère du Développement durable de l'Environnement et des Parcs. (2012). Directive 019 sur l'industrie minière. Québec, Québec: Gouvernement du Québec

Nemaska lithium, \& Agence canadienne d'évaluation environnementale. (2013). Projet Whabouchi: Développement et exploitation d'un gisement de spodumène sur le territoire de la baie-james - Étude des impacts sur l'environnement et le milieu social. Nemaska, Québec: Agence canadienne d'évaluation environnementale.

New Brunswick. (2015). Sisson mine project environmental impact assessment report summary - 2nd volume (65505). Napadogan, NB: New Brunswick.

Pokhrel, L. R., \& Dubey, B. (2013). Global Scenarios of Metal Mining, Environmental Repercussions, Public Policies, and Sustainability: A Review. Critical Reviews in Environmental Science and Technology, 43(21), 2352-2388. https://doi.org/10.1080/10643389.2012.672086

Québec. (2017). Loi sur le développement durable. (Chapitre D-8.1.1). Québec, Québec: Publications du Québec.

Rist, L., Felton, A., Samuelsson, L., Sandström, C., \& Rosvall, O. (2013). A new paradigm for adaptive management. Ecology and Society, 18(4), 63. https://doi.org/10.5751/ES-06183-180463

Roche ltée. (2000). Projet minier Niocan Inc. Étude environnementale - Rapport et annexes I à $V$. Sainte-Foy, Québec: Bureau d'Audiences Publiques sur l'Environnement.

Roche ltée. (2012). Projet minier Arnaud Inc. - Étude d'impact sur l'environnement - Volume 1 - Rapport principal (N/Réf: 59858). Québec, QC: Bureau d'Audiences Publiques sur l'Environnement.

Singh, K., Ihlenfeld, C., Oates, C., Plant, J., \& Voulvoulis, N. (2011). Developing a screening method for the evaluation of environmental and human health risks of synthetic chemicals in the mining industry. International Journal of Mineral Processing, 101(1-4), 1-20. https://doi.org/10.1016/j.minpro.2011.07.014

WSP Global. (2015). Projet Akasaba Ouest, Étude d'impact environnemental et social. Volume 1 - Rapport principal (Projet n¹41-14776-00). Montréal, QC: WSP Global.

\section{Appendix A}

Importance of the impact according to the value of the component as well as the intensity, extent and duration of the impact 


\begin{tabular}{|c|c|c|c|c|c|c|}
\hline \multirow{2}{*}{$\begin{array}{c}\text { Value of the } \\
\text { environmental } \\
\text { component }\end{array}$} & \multirow{2}{*}{$\begin{array}{l}\text { Intensity of } \\
\text { disturbance }\end{array}$} & \multirow{2}{*}{$\begin{array}{c}\text { Extent of } \\
\text { impact }\end{array}$} & \multirow{2}{*}{$\begin{array}{l}\text { Duration } \\
\text { of impact }\end{array}$} & \multicolumn{3}{|c|}{ Significance of impact } \\
\hline & & & & Strong & Average & Low \\
\hline \multirow{27}{*}{ Higher } & \multirow{9}{*}{ Strong } & \multirow{3}{*}{ Regional } & Long & $\mathbf{x}$ & & \\
\hline & & & Average & $\mathbf{x}$ & & \\
\hline & & & Short & $\mathbf{x}$ & & \\
\hline & & \multirow{3}{*}{ Topical } & Long & $\mathbf{x}$ & & \\
\hline & & & Average & $\mathbf{x}$ & & \\
\hline & & & Short & & $\mathbf{x}$ & \\
\hline & & \multirow{3}{*}{ Punctual } & Long & $\mathbf{x}$ & & \\
\hline & & & Average & & $\mathbf{x}$ & \\
\hline & & & Short & & $\mathbf{x}$ & \\
\hline & \multirow{9}{*}{ Average } & \multirow{3}{*}{ Regional } & Long & $\mathbf{x}$ & & \\
\hline & & & Average & $\mathbf{x}$ & & \\
\hline & & & Short & & $\mathbf{x}$ & \\
\hline & & \multirow{3}{*}{ Topical } & Long & $\mathbf{x}$ & & \\
\hline & & & Average & $\mathbf{x}$ & & \\
\hline & & & Short & & $\mathbf{x}$ & \\
\hline & & \multirow{3}{*}{ Punctual } & Long & & $\mathbf{x}$ & \\
\hline & & & Average & & $\mathbf{x}$ & \\
\hline & & & Short & & & $\mathbf{x}$ \\
\hline & \multirow{9}{*}{ Low } & \multirow{3}{*}{ Regional } & Long & $\mathbf{x}$ & & \\
\hline & & & Average & & $\mathbf{x}$ & \\
\hline & & & Short & & $\mathbf{x}$ & \\
\hline & & \multirow{3}{*}{ Topical } & Long & & $\mathbf{x}$ & \\
\hline & & & Average & & $\mathbf{x}$ & \\
\hline & & & Short & & & $\mathbf{x}$ \\
\hline & & \multirow{3}{*}{ Punctual } & Long & & $\mathbf{x}$ & \\
\hline & & & Average & & & $\mathbf{x}$ \\
\hline & & & Short & & & $\mathbf{x}$ \\
\hline \multirow{12}{*}{ Medium } & \multirow{9}{*}{ Strong } & \multirow{3}{*}{ Regional } & Long & $\mathbf{x}$ & & \\
\hline & & & Average & $\mathbf{x}$ & & \\
\hline & & & Short & & $\mathbf{x}$ & \\
\hline & & & Long & $\mathbf{x}$ & & \\
\hline & & Topical & Average & $\mathbf{x}$ & & \\
\hline & & & Short & & $\mathbf{x}$ & \\
\hline & & & Long & & $\mathbf{x}$ & \\
\hline & & Punctual & Average & & $\mathbf{x}$ & \\
\hline & & & Short & & & $\mathbf{x}$ \\
\hline & & & Long & $\mathbf{x}$ & & \\
\hline & Average & Regional & Average & $\mathbf{x}$ & & \\
\hline & & & Short & & $\mathbf{x}$ & \\
\hline
\end{tabular}




\begin{tabular}{|c|c|c|c|c|c|c|}
\hline & & \multirow{3}{*}{ Topical } & Long & $\mathbf{x}$ & & \multirow[b]{3}{*}{$\mathbf{x}$} \\
\hline & & & Average & & $\mathbf{x}$ & \\
\hline & & & Short & & & \\
\hline & & \multirow{3}{*}{ Punctual } & Long & & $\mathbf{x}$ & \\
\hline & & & Average & & & $\mathbf{x}$ \\
\hline & & & Short & & & $\mathbf{x}$ \\
\hline & \multirow{9}{*}{ Low } & \multirow{3}{*}{ Regional } & Long & & $\mathbf{x}$ & \\
\hline & & & Average & & $\mathbf{x}$ & \\
\hline & & & Short & & & $\mathbf{x}$ \\
\hline & & \multirow{3}{*}{ Topical } & Long & & $\mathbf{x}$ & \\
\hline & & & Average & & & $\mathbf{x}$ \\
\hline & & & Short & & & $\mathbf{X}$ \\
\hline & & \multirow{3}{*}{ Punctual } & Long & & & $\mathbf{x}$ \\
\hline & & & Average & & & $\mathbf{x}$ \\
\hline & & & Short & & & $\mathbf{x}$ \\
\hline \multirow{27}{*}{ Low } & \multirow{9}{*}{ Strong } & \multirow{3}{*}{ Regional } & Long & $\mathbf{x}$ & & \\
\hline & & & Average & & $\mathbf{x}$ & \\
\hline & & & Short & & $\mathbf{x}$ & \\
\hline & & \multirow{6}{*}{ Punctual } & Long & & $\mathbf{x}$ & \\
\hline & & & Average & & $\mathbf{x}$ & \\
\hline & & & Short & & & $\mathbf{x}$ \\
\hline & & & Long & & $\mathbf{x}$ & \\
\hline & & & Average & & & $\mathbf{x}$ \\
\hline & & & Short & & & $\mathbf{x}$ \\
\hline & \multirow{9}{*}{ Average } & \multirow{3}{*}{ Regional } & Long & & $\mathbf{x}$ & \\
\hline & & & Average & & $\mathbf{x}$ & \\
\hline & & & Short & & & $\mathbf{x}$ \\
\hline & & & Long & & $\mathbf{x}$ & \\
\hline & & Topical & Average & & & $\mathbf{x}$ \\
\hline & & & Short & & & $\mathbf{x}$ \\
\hline & & & Long & & & $\mathbf{x}$ \\
\hline & & Punctual & Average & & & $\mathbf{x}$ \\
\hline & & & Short & & & $\mathbf{x}$ \\
\hline & & & Long & & $\mathbf{x}$ & \\
\hline & & Regional & Average & & & $\mathbf{x}$ \\
\hline & & & Short & & & $\mathbf{x}$ \\
\hline & & & Long & & & $\mathbf{x}$ \\
\hline & Low & Topical & Average & & & $\mathbf{x}$ \\
\hline & & & Short & & & $\mathbf{x}$ \\
\hline & & & Long & & & $\mathbf{x}$ \\
\hline & & Punctual & Average & & & $\mathbf{x}$ \\
\hline & & & Short & & & $\mathbf{x}$ \\
\hline
\end{tabular}

2018, Vol. 7, No. 2 
Appendix B. Symbolic matrix on Excel sheet

Table B1. Post-EIA step matrix

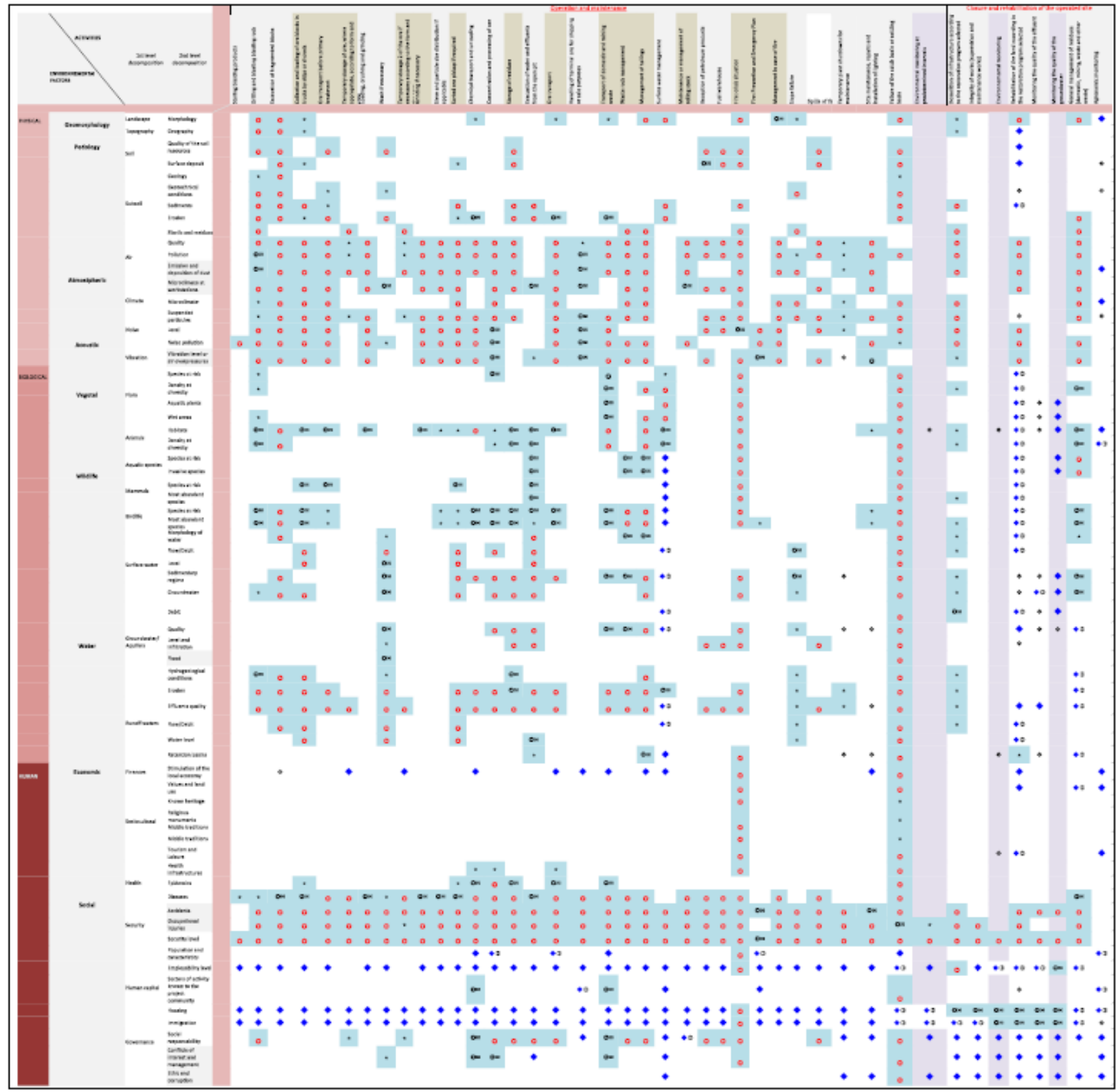


Table B2. EIA step

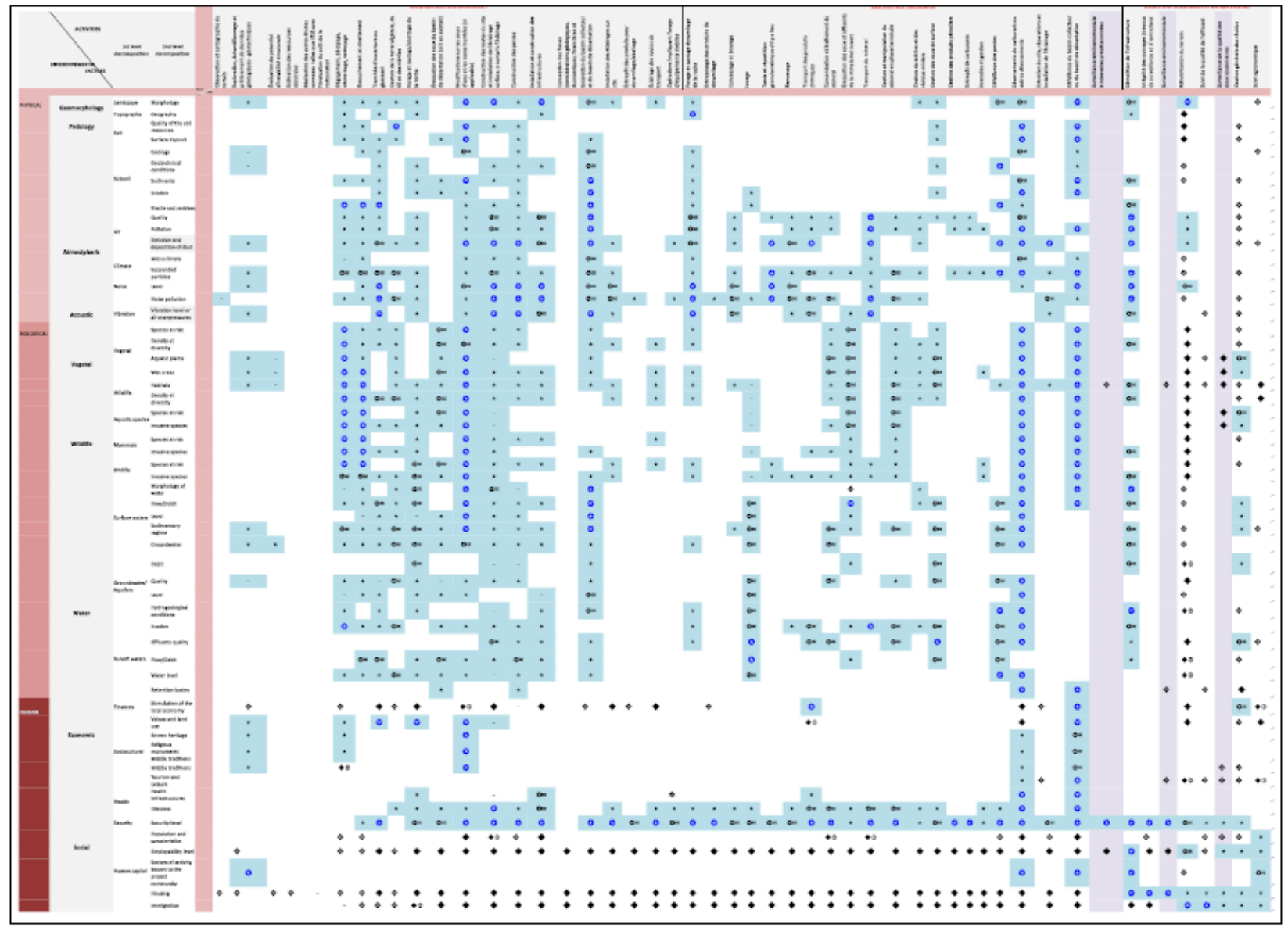


Appendix C

Numerical matrix on Excel sheet

Table C1. Post-EIA step

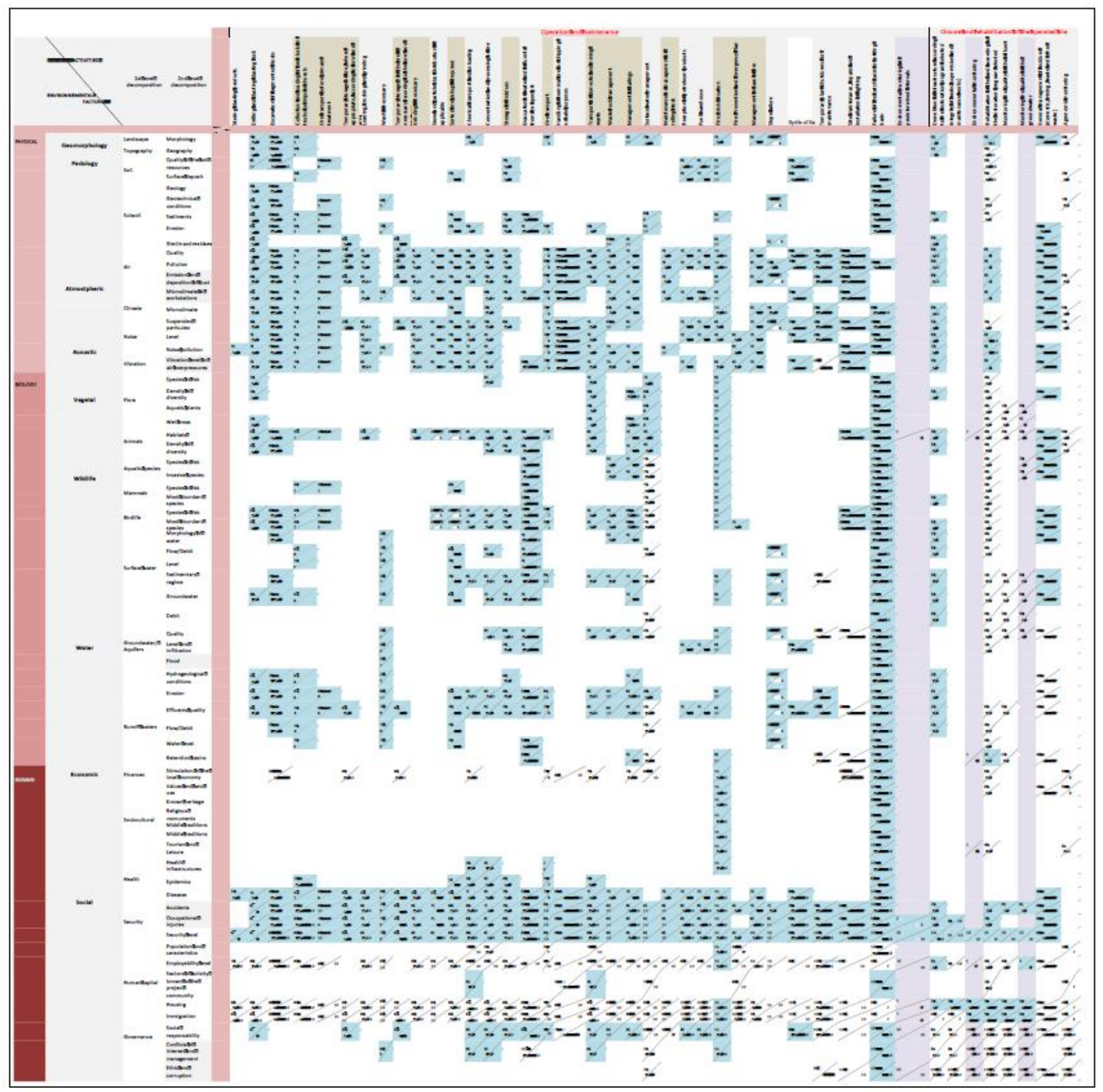


Table C2. EIA step

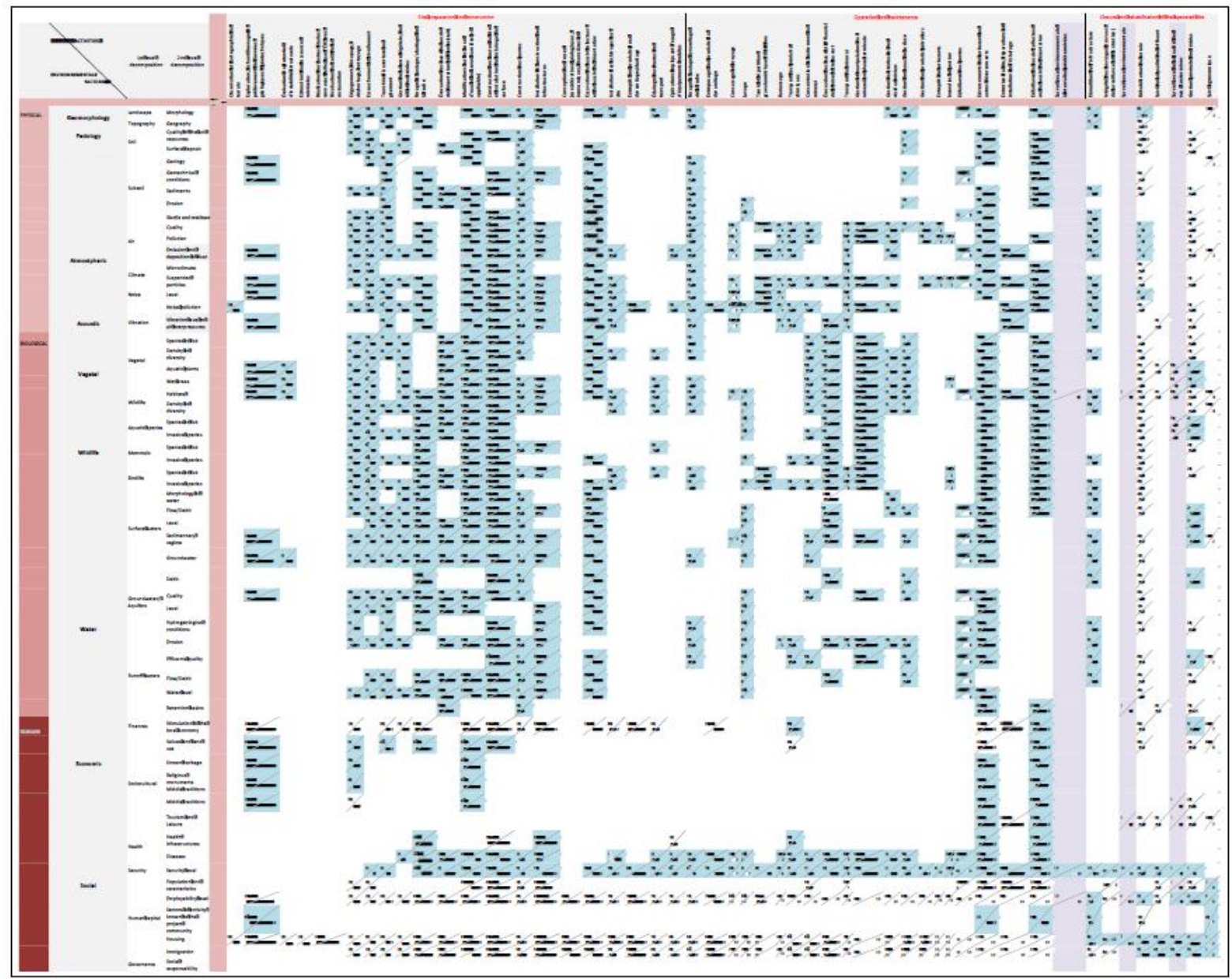

\section{Appendix D}

\section{Overview of the environmental components family score}

\begin{tabular}{|c|c|c|c|c|c|c|c|c|c|c|c|c|c|c|c|c|c|c|}
\hline \multirow{3}{*}{$\begin{array}{l}\begin{array}{l}\text { Environmental } \\
\text { components }\end{array} \\
\text { Phases }\end{array}$} & \multicolumn{8}{|c|}{ PHYSIQUE } & \multicolumn{6}{|c|}{ MOLOGIQUE } & \multicolumn{4}{|c|}{ HUMAN } \\
\hline & \multicolumn{2}{|c|}{ Geomorphological } & \multicolumn{2}{|c|}{ Soil } & \multicolumn{2}{|r|}{ Air } & \multicolumn{2}{|c|}{ Acoustic } & \multicolumn{2}{|c|}{ Vegetal } & \multicolumn{2}{|c|}{ Wildilite } & \multicolumn{2}{|c|}{ Water } & \multicolumn{2}{|c|}{ Economic } & \multicolumn{2}{|c|}{ Social } \\
\hline & $\begin{array}{l}\text { Project } \\
\text { phase }\end{array}$ & $\begin{array}{l}\text { Operation } \\
\text { phase }\end{array}$ & $\begin{array}{l}\text { Projett } \\
\text { phase }\end{array}$ & $\begin{array}{l}\text { Operation } \\
\text { phase }\end{array}$ & $\begin{array}{l}\text { Projet } \\
\text { phase }\end{array}$ & $\begin{array}{l}\text { Operation } \\
\text { phase }\end{array}$ & $\begin{array}{l}\text { Project } \\
\text { phase }\end{array}$ & $\begin{array}{l}\text { Operation } \\
\text { phase }\end{array}$ & $\begin{array}{l}\text { Project } \\
\text { phase }\end{array}$ & $\begin{array}{l}\text { Operation } \\
\text { phase }\end{array}$ & $\begin{array}{l}\text { Projett } \\
\text { phase }\end{array}$ & $\begin{array}{l}\text { Operation } \\
\text { phase }\end{array}$ & $\begin{array}{l}\text { Projet } \\
\text { phasse }\end{array}$ & $\begin{array}{l}\text { Operation } \\
\text { phase }\end{array}$ & $\begin{array}{l}\text { Project } \\
\text { phase }\end{array}$ & $\begin{array}{l}\text { Operation } \\
\text { phase }\end{array}$ & $\begin{array}{l}\text { Project } \\
\text { phase }\end{array}$ & $\begin{array}{l}\text { Operation } \\
\text { phase }\end{array}$ \\
\hline
\end{tabular}

\section{Copyright Disclaimer}

Copyright for this article is retained by the author(s), with first publication rights granted to the journal.

This is an open-access article distributed under the terms and conditions of the Creative Commons Attribution license (http://creativecommons.org/licenses/by/3.0/). 